CHOICE OF A WILDFIRE RISK SYSTEM FOR EUCALYPTUS PLANTATION: A

Fernando Coelho Eugenio ${ }^{a^{*}}$; Alexandre Rosa dos Santos ${ }^{b}$; Beatriz Duguy Pedra ${ }^{c}$; José Eduardo Macedo Pezzopane ${ }^{b}$; Lima Deleon Martins ${ }^{d}$; Cássio Carlette

7 a) Department of agricultural engineering, Federal University of Santa Maria,

8 Cachoeira do Sul, Rio Grande do Sul, Brazil

9 b) Department of Forest Sciences, Federal University of Espírito Santo, Jerônimo

10 Monteiro, Espírito Santo, Brazil

11 c) Department of Evolutive Biology, Ecology and Environmental Sciences, University

12 of Barcelona, Barcelona, Spain

13 d) PostGraduate Programme in Plant Production, Federal University of Espírito,

14 Aegre, Espírito Santo, Brazil

$15{ }^{*}$ Corresponding author:

16 E-mail: fernando.eugenio@ufsm.br (FCE)

\title{
$17{ }^{*}$ Contributions
}

Fernando Coelho Eugenio: Main author of the article, led and coordinated the 20 research and writing.

21 Alexandre Rosa dos Santos: Advisor of the doctoral thesis, to which this article is 22 fruit, it was he who directed the research.

23 Beatriz Duguy Pedra and José Eduardo Macedo Pezzopane: Co-advisors of the 24 doctoral thesis, which this article is fruit, both helped in directing the research and the 25 discussion of the article.

26 Lima Deleon Martinsd, Cássio Carlette Thiengo and Nathália Suemi Saito: Both

27 helped in the final writing of the article and in the analysis of all the historical series

28 used in the article, is associated to them the part of the statistic in the discussion of 29 the article. 


\section{ABSTRACT}

34 With the advent of computation and the progressive advancement of geotechnologies,

35 the use of mathematical models of wildfire risk became more expressive in quantitative

36 terms. The existence of a significant and variable number of models of wildfires risk

37 presents the necessity to select the model that best fits a probable region - which can

38 be done in two ways: visually or through the confrontation of existing models. In this

39 sense, the present study aims at selecting the wildfire risk models $\mathrm{FWI}, \mathrm{FMA}^{+}$and RIF-

40 Database for the Eucalyptus plantations. The study area extends from the north-

41 central coast of the state of Espírito Santo and the south coast of Bahia, Brazil. The

42 database was comprised the period between January 1st, 2010 to June 30st, 2016,

43 with 10,447 occurrences. The validation and choice of the results were determined by

44 the success percentages and the skill score value, for each subzone and risk model.

45 After, it was performed the parametric analysis of Variance Analysis (ANOVA), if the

$46 \quad F$ test was significant, the Tukey-Kramer post-hoc test $(p<0.05)$ was used to compare

47 all the ids with each other. We observed in days with wildfire, a greater sensitivity of

48 the $\mathrm{FMA}^{+}$model, which presented success percentage values higher than $60 \%$ for all

49 subzones. However, it presented the worst results for the days without wildfire and,

50 consequently, the worst results for the overall success rate. Additionally, considering

51 the skill score value, the FWI model presented the best results for subzone 1 . The

52 RIF-Database model presented excellent results, being the model to be used for

53 subzones 2 and 3.

54

55 Keywords: Climate change, geotechnologies, mathematical models. 


\section{Introduction}

Wildfires are results by the complex interactions between vegetation, climate, topography and anthropogenic activities over time. However, local climatic conditions have a direct influence your occurrence and how they spread, given that the intensity of a fire and the speed with which it advances are directly linked to as relative air humidity, air temperature and wind speed, since it affects the moisture content of the fuel, amount of biomass, which is the main controller of the principal fire characteristics, in addition to the type of vegetation found (Chang et al., 2015). Therefore, because of its ability to provide quantitative estimates of the possibility of forest fire occurrence, the hazard indices based on meteorological data, have become important tools to evaluate the potential risk of regional fires (Holsten et al., 2013).

Actually, with the advent of computation and the progressive advancement of geotechnologies, the use of mathematical models concerning the risk of occurrence, danger and the form of propagation of a wildfire became more expressive in quantitative terms. It is believed that the next step in regression models estimating forest fire hazard occurs through complex interactions using nonlinear algorithms in artificial intelligence. However, there are currently several mathematical models that are used around the world to estimate wildires risk, for example, the indexes that were used in this article: Forest Weather Index - FWI, Modified Monte Alegre Formula $\mathrm{FMA}^{+}$and models developed for specific databases, the RIF-Database.

The FWI system was developed for a standard type of forest fuel from the pine forests of a region of Canada, but since its creation the system has been used as a general measure of wildfire hazard throughout Canada (Van Wagner, 1987). The FWI system is used in different parts of the world, covering different types of ecosystems. However, its correct application is conditional on the use of a reliable database and a calibration process (Van Wagner, 1987; Viegas et al., 2004; Carvalho et al., 2008; Dacamara et al., 2014).

Soares (1972) developed the first fire risk index for brazilian conditions, the Monte Alegre Formula (Fórmula de Monte Alegre - FMA). In a simplistic view, it can be said that the FMA is a cumulative index that uses as meteorological variables the relative air humidity and the precipitation. From the understanding of the need to

89 include some index for the propagation of the fire in the structure of the FMA, Nunes

90 (2005) added the wind speed, factor of great importance for the prevention and mainly 
91 for wildfires fighting, thus developing the Modified Monte Alegre Formula (Fórmula de

92 Monte Alegre Alterada - $\mathrm{FMA}^{+}$), which was tested and approved for use in the region

93 of Telêmaco Borba, state of Paraná, Brazil.

The Universal Forest Fire Risk System (RIF-Database) is based on meteorological databases and the occurrence of forest fires in eucalyptus plantations, was obtained through language Transact-SQL. According to Eugenio (2017), the RIFDatabase is a new path for existing fire risk models because it is part of one of the databases that can be fed over the days, calculating the system, acquiring greater sensitivity to the area to which it is being applied.

The existence of a significant and variable number of models of wildfires presents the necessity to select the model that best fits a probable region - which can be done in two ways: visually or through the confrontation of existing models.

Lawson and Marion (2008) argue that visual choice is very subjective, since there are several aspects on which the decision can be based, such as: generality, computational requirements, predictive capacity, among others not counted in subjective decisions. However, a visual analysis of the models - although subjective is supported by Finney (2000) in the comparison of real and simulated perimeters.

Busemeyer and Wang (2000) report that the models originated with the aid of technology obtained a gain in complexity. As a result, there was a need to create rigorous methods for comparison. The authors indicate that it is possible - even after the comparison of models - to obtain a model that is "better than another" because

112 there is a more flexible function or a greater diversity of parameters, and not because 113 it is based on better scientific principles.

114 Viegas et al. (1999) argue that the task of comparing various models of wildfire risk is very difficult because not only the empirical - and sometimes subjective - nature

116 of the formulation of wildfire hazard indexes but also the different levels of complexity

117 of the existing methods with their various input and output parameters are taken into 118 account.

119 Haines et al. (1985) analyzed some particular models of the National Fire Danger 120 Rating System (NFDRS) and affirm that it is necessary to submit the different models 121 to the same set of meteorological and fire data in order to better evaluate them. Paixão 122 (2015) carried out the comparison of four fuel models, through a computer application, 123 for an area of 29,000 ha in the Serra de Portel, Portugal - such comparison was based 124 on statistical analysis. Considering what is stated above, the present study aims at 
selecting the wildfire risk models $\mathrm{FWI}, \mathrm{FMA}^{+}$and RIF-Database for the Eucalyptus plantations on the north-central coast of the state of Espírito Santo and the south coast of Bahia, Brazil.

\section{Material and methods}

\subsection{Study area and database}

132

The study area extends from the north-central coast of the state of Espírito Santo to the south coast of Bahia state, as described by Eugenio (2017) for the delimitation of the area was used a buffer of $70 \mathrm{~km}$ from the coast, because, within this buffer are the region that concentrates the largest number of planted eucalyptus forests and all meteorological stations of forestry companies. The study area was divided into three climatic subzones and the occurrences of wildfires and their climatic subzones can be observed in Figure 1.

\subsection{Data processing and statistical analysis}

\subsubsection{Database preparation and risk calculation}

143 Data on the number of wildfires and meteorological variables were acquired from

144 Fibria Celulose S.A during the period comprised between January 1st, 2010 to June 145 30st, 2016. The database has several information about the fires occurring in the 146 region, such as: geographical location, date of occurrence, burned area, time of 147 occurrence. An analysis was performed to remove duplicated information within the 148 database, which was based on the identical geolocation search on the same date of 149 occurrence, thus, eliminating the flaws. With the adjusted database, the occurrences 150 of wildfires were plotted in the Geographic Information Systems (GIS) environment by providing the ArcGIS 10.3 software application.

152 The study had data from 20 meteorological stations, for each station - regardless

153 of its geographic location in the study area - the wildfire risk values were calculated 154 using the following models: FWI, carried out through an Excel® supplement provided 155 by the Canadian Forest Service ${ }^{1}$ following classes were defined according to

\footnotetext{
${ }^{1}$ Linked to the research conducted by Dr. Beatriz Duguy Pedra for the European project FUME (Forest fires under climate, social and economic changes in Europe - the Mediterranean and other fire-affected areas of the world - GA 243888) http: //cordis.europa. I / result / rcn / 90753_en.html
} 
meteodology proposed by Eugenio (2017); $\mathrm{FMA}^{+}$, carried out through the software developed by Eugenio (2017), based on the equation conceived by Nunes (2009); and, RIF-Database, risk calculation performed using the database-base system prepared by Eugenio (2017). After the calculation, the occurrences were separated according to the area of coverage of subzones 1,2 and 3 .

\subsubsection{Distribution of wildfire risk values for each risk class}

The FWI, $\mathrm{FMA}^{+}$and RIF-Database models have different intervals for each risk class and subzone, as can be seen in Table 1. Therefore, the grouping was done according to each risk class.

\subsubsection{Creation of new spreadsheets according to the occurrence or not of wildfires}

According to its class, the separation of the days with and without occurrence of wildfires was made. Since each station has an area of coverage, consequently, it is possible to have knowledge of the dates when there was a wildfire within that area.

\subsubsection{Analysis of the results of the classes found}

After the calculation and determination of the values for each class, the fire risk behavior was obtained for the different methodologies.

In order to analyze the risk behavior of the RIF-Database, $\mathrm{FWI}$ and $\mathrm{FMA}^{+}$models in the different classes, a cross-reference of the calculated risk and the dates of the wildfire were performed. It was used the Skill score (SS) and Percentage of Success (PS) as was used in the works of Sampaio (1999), Nunes (2005), Nunes et al. (2006), Borges (2011) and Dimitrakoupolos et al. (2011).

This method provided the estimate of the assertiveness of each calculated risk, since it is based on the ratio of the difference between the correctness of the prediction and the expected number of hits, as well as the difference between the number of days observed and the number of days (Table 2 ).

The equations for performing the calculations were:

$186 N=a+b+c+d$

187 Where: $N=$ total number of observations; $a=$ number of days with occurrences of expected and observed fires; $b=$ number of days with occurrences of expected fires 
and not observed; $c=$ number of days with occurrences of fires not expected and observed; and $d=$ number of days with occurrences of fires not expected and not observed.

194 Where: $G_{a}=$ number of hits in the forecast.

Where: $H_{a}=$ expected number of hits; $p=N_{1} / N=$ number of days with occurrences of expected and observed fires; $q=N_{2} / N=$ number of days with occurrences of fires anticipated and not observed; $N_{1}=$ number of days with occurrences of fires planned and observed more number of days with occurrences of fires not expected and observed; $N_{2}=$ number of days with occurrences of fires anticipated and observed more number of days with occurrences of fires anticipated and not observed; $N_{3}=$ number of days with occurrences of fires expected and not observed plus number of fires days with occurrences of unexpected and unobserved fires; $N_{4}=$ number of days with occurrences of fires not expected and observed more number of days with occurrences of fires not expected and not observed; $p=$ number of days with occurrences of fires expected and observed more number of occurrences of unexpected and observed fires occurring, divided by the total number of comments; and $q=$ number of days with occurrences of expected fires and observed more number

210 of days with occurrences of expected and unobserved fires, divided by the total 211 number of observations.

214 Where: $S S=$ skill score.

217 Where: $P S$ : percentage of success. 


\subsubsection{Choose the template}

The choice of the model is a crucial step for the correct use of a risk index. The methods used in the present study consisted in the validation and choice of the results presented by the success percentages and the skill score value, for each subzone and risk model. Initially, normalization of success percentage data with and without fires, general and skill score values, was normalized, with the values ranging from 0 to 100 .

After the normalization of the values, the hypothesis test is carried out using the Shapiro-Wilk test, in order to know if the sample is or is not coming from a normal distribution. $\mathrm{H}_{0}$ : The sample comes from a normal distribution and, $\mathrm{H}_{1}$ : The sample does not come from a normal distribution.

If the sample comes from a normal distribution, it was performed the parametric analysis of Variance Analysis (ANOVA), which has as hypothesis the equality between the means of two or more populations. If the $F$ test was significant, the Tukey-Kramer post-hoc test $(p<0.05)$ was used to compare all the ids with each other. Given that, the highest average value will be the model chosen.

On the other hand, if the sample did not come from a normal distribution, the Kruskall-Wallis non-parametric analysis of variance was used, and the null hypothesis is the equality between the models in each subzone, at the level of significance equal to 0.05 and confidence interval equal to $95 \%$.

This methodology aims at solving a difficult situation experienced in the areas of forests planted in the central-north coast of Espírito Santo and the south coast of Bahia, since in this region there are about $92 \%$ of the days without the occurrence of wildfires and only $8 \%$ days with wildfires. Added to this factor, we have that the area has a history of criminal fires, thus reducing the relationship between the variables and their response in the model. All five steps necessary to carry out the present methodology are represented in Figure 2.

\section{Results and discussion}

The results found for the success percentage of the days with and without fire, general and skill score tests are presented in Table 3.

For the days with wildfire, it was observed a greater sensitivity of the FMA

252 However, it presented the worst results for the days without wildfire and, consequently, 253 the worst results for the overall success rate. 
254 Regarding the percentage of general success obtained for the $\mathrm{FMA}^{+}$in both 255 subzones, the results found in the present study are (in an average) very close to 256 those found by Nunes (2005), Nunes et al. (2006) and Nunes et al. (2010), which 257 obtained a value of $55.64 \%$. However, for the skill score test it was found lower values 258 than those found by the same authors, who obtained a value of 0.11165 for the test.

259 It is noted the greater accuracy of the $\mathrm{FMA}^{+}$model for both subzones, as 260 discussed previously. It is also worth noting that for subzone 3 there is a reversal of 261 the percentage of correctness between the FWI and RIF-Database models, with the 262 RIF-Database exceeding the FWI in this subzone with $5.50 \%$ more, however, it is still 263 a low hit, being it of $40.66 \%$.

264 In relation to the success rate of the days without wildfire, there is a reversal in 265 the role of the models, and the RIF-Database model presents the highest sensitivity 266 for the accuracy of days without wildfire.

267 For the days in which did not occur wildfires, the RIF-Database model presented 268 success percentage values above $80 \%$ for all subzones and, consequently, the best 269 results for the percentage of general success with an average close to $80 \%$. It is also 270 worth noting the values obtained by the FWI model for the days without wildfire, which 271 has an average over $70 \%$.

272 The result of the overall success percentage of the days with and without wildfire 273 is consistent with what was expected, since the greatest hit of the days without wildfire 274 is directly correlated with the greater overall score, since there is no homogeneous 275 distribution between days with and without wildfire in the study area.

$276 \quad$ For all subzones the RIF-Database model was the best, overcoming all fire risk 277 studies in Brazil. It is expected that a fire risk model that was based and fed by data 278 from the study area would obtain the best results, however, it is also worth noting the 279 average of $70 \%$ for the FWI model, which can be considered excellent because it surpasses several studies carried out in the country.

281 The RIF-Database and FWI models obtained results above those found by 282 Souza (2014), 63.53\%; Rodríguez et al. (2012), 57.10\%; and Borges et al. (2011), who 283 found success percentage values ranging from 51.54 to $56.47 \%$.

284 White et al. (2013) and White et al. (2015) obtained as result the percentage of 285 success of $\mathrm{FMA}^{+}$in areas with eucalyptus plantations in the north coast of Bahia, 
values of $38.64 \%$ and $36 \%$, respectively - values that are much lower than those found in the present study.

288 White (2010) obtained a percentage of success of $73 \%$ when analyzed the FMA $289+$ and the hot spots for the state of Sergipe - values similar to the one found for the FWI model in the present study and below those found by the RIF-Database model.

In relation to the overall success percentage for the FWI model, the values found in the present study are higher than those found in Sampaio (1999), which obtained a 293 value of $52.81 \%$ for the region of Agudos, São Paulo. Viegas et al. (s.d. apud SAMPAIO, 1999) found success percentage values for southern European regions corresponding to $75.5 \%$ for $\mathrm{FWI}$, a value close to that found for the present study region.

The average found by the skill score test for the subzones was 0.1217 for the FWI model, 0.0777 for the $\mathrm{FMA}^{+}$and 0.2312 for the RIF-Database model. White et al. (2013), when evaluating $\mathrm{FMA}^{+}$in areas of eucalyptus plantations on the northern coast of Bahia from 01/01/2002 to 31/12/2009, found a skill score equal to 0.059; and White et al. (2015), for the period that ranged from $01 / 01 / 2002$ to $31 / 12 / 2012$, found a skill score equal to 0.05 (Figure 3). Rodríguez et al. (2012) evaluated the performance of wildfire risk indexes for the areas of the Macujire forest company, in Cuba, during the period that ranged from January 2006 to December 2011 and obtained for $\mathrm{FMA}^{+}$in the skill score test the value of 0.0737 . Both studies obtained averages lower than those found in the present study.

White (2010) provided the $\mathrm{FMA}^{+}$to calculate the risk of wildfires between 06/06/2008 and 11/08/2009 - the author describes in his study that for the wildfires that occurred in the Serra de Itabaiana National Park, Sergipe, Brazil, it was obtained a skill score equal to 0.023 (a lower value when compared to the one found in the present study); on the other hand, for the state of Sergipe and when analyzing the hotspots, the author found a value of 0.36 (value higher than that found in the present study).

Sampaio (1999), in his study for the region of Agudos, state of São Paulo, made 315 a comparison between different wildfire risk indexes, among them the FWI. The data 316 used by the author comprised the period between 1984 and 1995 and obtained as a 317 response of the best index - after adjustments - the FWI, which presented in the skill 
318 score test the value of 0.1363 ; a value similar to the average of the FWI model found 319 in the subzones of the present study.

White et al. (2013) carried out in their work a comparison between different wildfire risk indexes in the period of time comprised between the years of 2002 and 2009. The authors used the database of wildfires in eucalyptus plantations in the north coast of Bahia, Brazil, and obtained for the FWI a value of 0.053 for the skill score test, which is much lower when compared to the results obtained in the present study.

Borges et al. (2011) carried out a study to verify the performance of some fire risk indexes in eucalyptus plantations in the North of Espírito Santo from 2003 to 2004. The authors found skill score values ranging from 0.1626 to 0.2055 ; values higher than those found in the present study for the FWI and $\mathrm{FMA}^{+}$models, however, below the RIF-Database.

In work developed for southern European regions, Viegas et al. (apud SAMPAIO, 1999) found skill scores for the region of the province of the De-Haut Alps corresponding to 0.28 for the $\mathrm{FWI}$, a value above that found in the present study.

The choice of the model for each subzone was based on a statistical test. Initially,

334 it was performed a standardization of the success percentage data with and without fire, and also general and skill score values, being standardized to a scale ranging 336 from 0 to 100 . After standardization of the values, the hypothesis test was performed using the Shapiro-Wilk test, as can be seen in Table 4.

338 As can be observed, the ids presented values higher than 0.05 , therefore, the null hypothesis is accepted, so the sample comes from a normal distribution. The parametric analysis of the Analysis of Variance (ANOVA) was performed, which has as hypothesis the equality between the means of two or more populations - in the present case, the equality between the normalized values for each id. As the $F$ test was significant, the Tukey-Kramer post-hoc test was used to compare all the ids to 344 each other.

345 The Tukey-Kramer test was performed at the significance level of 0.05 and its $34695 \%$ confidence interval, and for both subzones the null hypothesis was not rejected, 347 that is, the distribution of normalized values is the same between the different 348 identifiers, for each subzone. Therefore, the choice of the best wildfire risk model for 349 each subzone was based on the highest average found. 
As can be seen in Table 6, the highest average value for subzone 1 was the FWI system with an average value of 35.11 ; for subzone 2 and 3 , the RIF-Database system was the chosen one, presenting an average value of 39.32 and 31.91, respectively.

It was expected that the RIF-Database model would present the best results and would be the model chosen for all the subzones since it was developed with daily meteorological data of the study area, however, for the subzone 1 the FWI model surpassed it. This fact is presented as a sign that the FWI model is rather a very efficient model for predicting wildfires in the study area.

Thus, the importance of the present study is emphasized, considering the risk of wildfires in Brazil, since it is still possible to improve the FWI system with the calibration of its parameters. Therefore, it is believed that with studies aimed at calibrating the FWI system together with the class identification methodology of the present study, the overall accuracy of the index may be even higher in relation to the other methodologies of fire risks adopted in Brazil.

\section{Conclusions}

The use of different data to choose the model was of fundamental importance. The FWI model presented the best results for subzone 1. The RIF-Database model presented excellent results, being the model to be used for subzones 2 and 3 . The FWI model is seen as the most successful model for the study area, since it found higher values for a subzone when compared to the model developed through the database of the study area, however, a study will be needed in order to calibrate its parameters.

\section{References}

Borges, T. E., Fiedler, N. C., Santos, A. R., Loureiro, E. B. and Mafia, R. G.: Desempenho de alguns índices de risco de incêndios em plantios de eucalipto no norte do Espírito Santo. Floresta e Ambiente, 18(2), 53-159, http://dx.doi.org/10.4322/floram.2011.033, 2011.

Busemeyer, J. R. and Wang, Y.: Model Comparisons and Model Selections Based on Generalization Criterion Methodology. Journal of Mathematical Psychology. 44 (1), 171-189, https://doi.org/10.1006/jmps.1999.1282, 2000.

Carvalho, A., Flannigan, M. D., Logan, K., Miranda, A. I. and Borrego, C.: Fire activity in Portugal and its relationship to weather and the Canadian Fire Weather Index System. Int J Wildland Fire,17, 328-338, https://doi.org/10.1071/WF07014, 2008. 
Dacamara, C. C., Calado, T. J., Ermida, S. L., Trigo, I. F., Amraoui, M. and Turkman, K. F.: Calibration of the fire weather index over mediterranean europe based on fire activity retrieved from MSG satellite imagery. International Journal Wildland Fire, v. 23, 945-958, https://doi.org/10.1071/WF13157, 2014.

Dimitrakopoulos, A., Bemmerzouk, A. and Mitsoupoloulos, I.: Evaluation of the Canadian fire weather index system in a eastern Mediterranean environment. Meteorological Applications, v.18, 83-93, https://doi.org/10.1002/met.214, 2011.

Eugenio, F. C.: Análise de risco de incêndios florestais em florestas plantadas. Thesis (Doutorado em Ciências Florestais) - Centro de Ciências Agrárias, Universidade Federal do Espírito Santo, Jerônimo Monteiro, 161 f., 2017.

Eugenio, F. C., Santos, A. R., Pedra, B. D., Pezzopane, J. E. M., Mafia, R. G., Loureiro, E. B., Martins, L. D. and Saito, N. S.: Causal, temporal and spatial statistics of wildfires in areas of planted forests in Brazil. Agricultural and Forest Meteorology, v. 266-267, https://doi.org/10.1016/i.agrformet.2018.12.014, 157-172, 2019.

Finney, M. A.: Efforts and comparing simulated and observed fire growth patterns. Final report. 20p. 2000.

Haines, D. A., Main, W.A. and Simard, A.J.: Operational validation of the NFDRS in the Northeast. In 'Proceedings of the Eight Conference on Fire and Forest Meteorology'. pp.169-177. (Society of American Foresters: Detroit, 29 April-2 May 1985) 1985.

Jolly, W. M., Cochrane, M. A., Freeborn, P. H., Holden, Z. A., Brown, T. J., Williamson, G. J., and Bowman, D. M.: Climateinduced variations in global wildfire danger from 1979 to 2013. Nature Communications, 6, https://doi.org/10.1038/ncomms8537, 2015.

Lawson, D.; Marion, G. 2008.: An introduction to mathematical modelling. 2008. 35p. Disponível em: <https://people.maths.bris.ac.uk/ madj//course_text.pdf>. Acesso em: 05 mar. 2017.

Nunes, J. R. S.: FMA+. Um novo índice de perigo de incêndios florestais para o Estado do Paraná - Brasil. 2005. 150f. Tese (Doutorado em Engenharia Florestal) Universidade Federal do Paraná, Curitiba. 2005.

Nunes, J. R. S., Soares, R. V. and Batista, A. C: FMA+: Um Novo Índice de Perigo de Incêndios Florestais para o Estado do Paraná - Brasil. Floresta, Curitiba, 36(1), 178-179, http://dx.doi.org/10.5380/rf.v36i1.5509, 2006.

Nunes, J. R. S., Soares, R. V. and Batista, A. C.: Análise da fórmula de monte alegre $(\mathrm{FMA}+)$ para o estado do Paraná. Floresta, Curitiba, 39(3), 473-484, http://dx.doi.org/10.5380/rf.v39i3.15348, 2009.

Paixão, L. G. M. A.: Simulação de comportamento de fogo em zonas florestais no alentejo central: comparação de modelos de combustível. 75f. Dissertação (Mestrado em Ciência e Sistemas de Informação Geográfica) - Universidade Nova de Lisboa. Lisboa. 2015.

Rodríguez, M. P. R., Soares, R. V., Batista, A. C., Tetto, A. F., Sierra, C. A. M. and Rodríguez, Y. C. Ajuste e desempenho dos índices de perigo de incêndios 
Nesterov, FMA e FMA+ na empresa florestal Macujire, Cuba. Floresta, 42(4), 651-660, http://dx.doi.org/10.5380/rf.v42i4.28659, 2012.

Sampaio, O. B.: Análise da eficiência de quatro índices na previsão de incêndios florestais para a região de Agudos - SP [Thesis]. Curitiba: Universidade Federal do Paraná; 157 p. 1999.

Soares, R.V.: Indices of fire hazard. Floresta, 3, 19-40, http://dx.doi.org/10.1590/180690882018000300006, 1972.

Souza, J. I.: Comportamento e ajustes dos índices de perigo de incêndio - FMA e FMA+ para o município de Lages-SC. 93 f. Dissertação (Mestrado em Engenharia Florestal) - Universidade Estadual de Santa Catarina. Lages. 2014.

Van Wagner, C.E.: Development and structure of the Canadian Forest Fire Weather Index System. Can. For. Serv., Ottawa, ON. For. Tech. Rep. 35. 37 p, 1987.

Viegas, D.X., Sol, B., Bovio, G., Nosenzo. A., and Ferreira A.D.: Comparative study of various methods of fire danger. International Journal of Wildland Fire,1999. 235-246. http://dx.doi.org/10.1071/WF00015, 1999.

Viegas, D.X., Reis, R.M., Cruz, M.G. and Viegas, M., T.: Calibração do sistema canadiano de perigo de incêndio para aplicação em Portugal. Silva Lusitana, 12, 1, 77-93, 2004

White, A. A. S., White, B. L. A. and Ribeiro, G. T.: Evaluation of forest fire danger indexes for eucalypt plantations in Bahia. Brazil. International Journal of Forestry Research, 6p. http://dx.doi.org/10.1155/2015/613736, 2015.

White, B. L. A.: Incêndios florestais no Parque Nacional Serra de Itabaiana, Sergipe. 142 f. Dissertação (Mestrado em Desenvolvimento e Meio Ambiente) Universidade Federal de Sergipe. São Cristóvão, 2010.

White, B. L. A., White, L. A. S., Ribeiro, G. T. and Fernandes, P. A. M.: Development of a fire danger index for eucalypt plantations in the northern coast of Bahia, Brazil. Floresta, 43(4), 601-610, http://dx.doi.org/10.5380/rf.v43i4.30973, 2013.

459

460 
463 Figure 1 Study area and its climatic delimitations for wildfires. 16

464 Figure 2 Flowchart of the steps required to carry out the methodology...... 17

465 Figure 3 Results obtained by the skill score tests for the class values of the FWI, FMA

472 Table 1 Limit values of the classes of wildfire risk classes $\mathrm{FWI}, \mathrm{FMA}^{+}$and RIF-

474 Table 2 Difference between the number of days observed and the number of days 19

475 Table 3 Results obtained by the percentage success for the class values of the FWI,

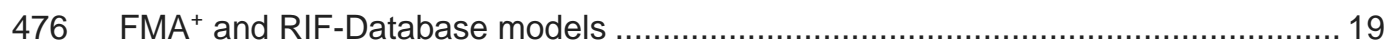

477 Table 4 Results found with the Shapiro-Wilk test for the different ids. ..................... 19 
https://doi.org/10.5194/nhess-2019-350

Preprint. Discussion started: 27 November 2019

(c) Author(s) 2019. CC BY 4.0 License.
Natural Hazards 웅 and Earth System

Sciences

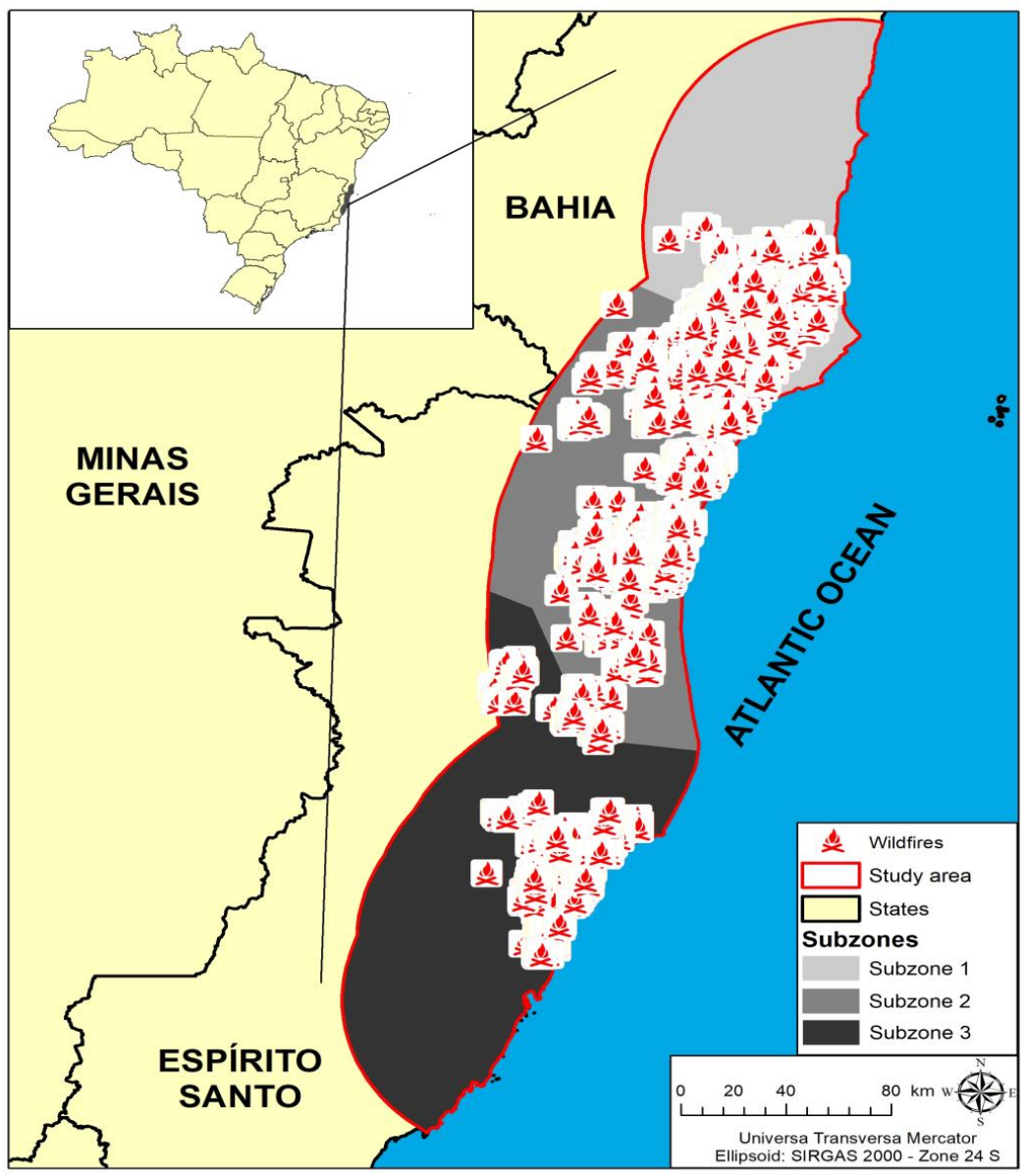


https://doi.org/10.5194/nhess-2019-350

Preprint. Discussion started: 27 November 2019

(c) Author(s) 2019. CC BY 4.0 License.
Natural Hazards 웅 and Earth System Sciences

Discussions

Figure 2 Flowchart of the steps required to carry out the methodology.

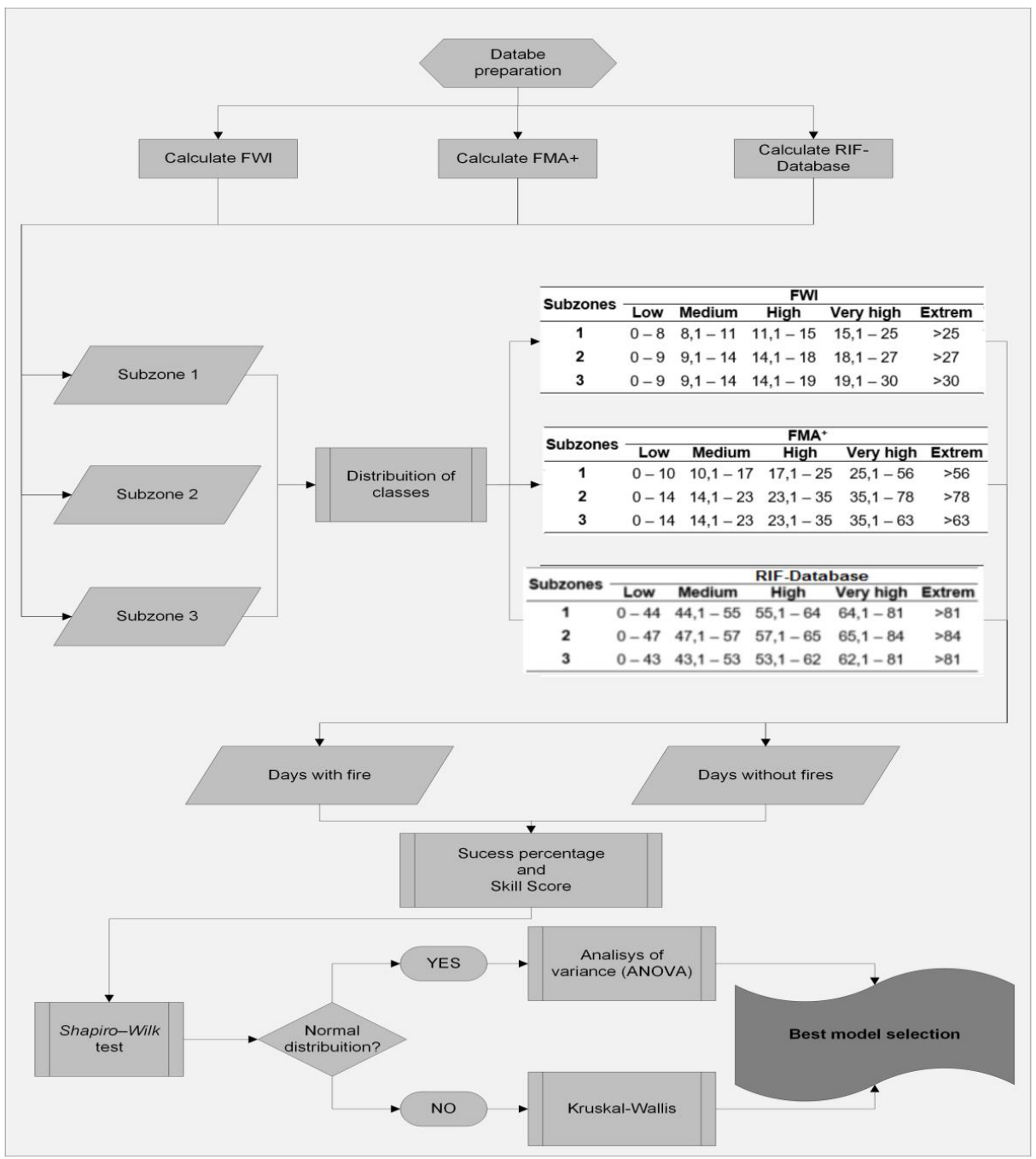


Figure 3 Results obtained by the skill score tests for the class values of the FWI, FMA ${ }^{+}$and RIF-Database models

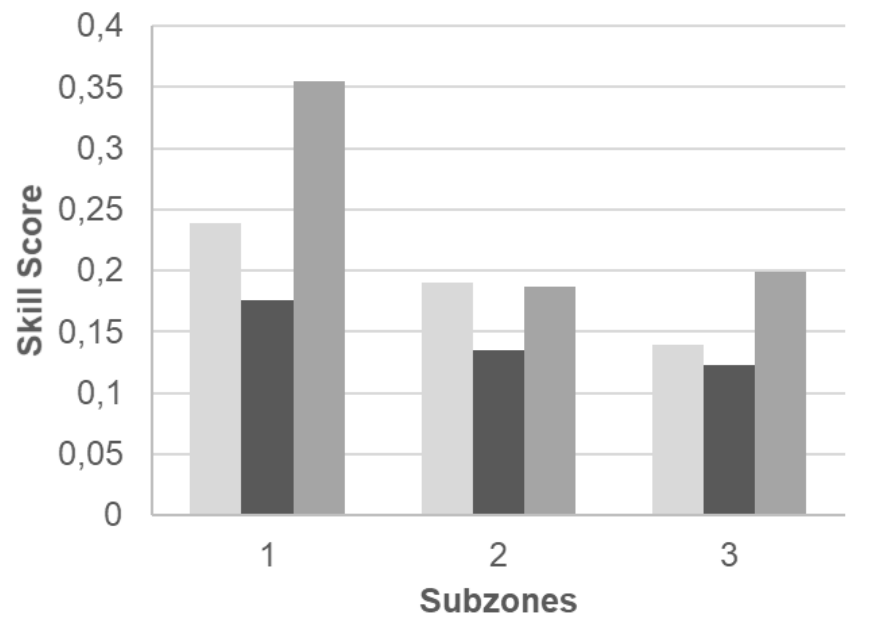

$\square \mathrm{FWl}$

- FMA+

- RIF-Database

491

492 
Table 1 Limit values of the classes of wildfire risk classes FWI, FMA ${ }^{+}$and RIF-Database.

\begin{tabular}{ccccccc}
\hline \multirow{2}{*}{ model } & \multirow{2}{*}{ subzones } & \multicolumn{5}{c}{ classes of wildfire risk } \\
\cline { 2 - 6 } & & low & medium & high & very high & extrem \\
\hline \multirow{2}{*}{ FWI } & 1 & $0-8$ & $8.1-11$ & $11.1-15$ & $15.1-25$ & $>25$ \\
& 2 & $0-9$ & $9.1-14$ & $14.1-18$ & $18.1-27$ & $>27$ \\
\multirow{2}{*}{ FMA+ } & 3 & $0-9$ & $9.1-14$ & $14.1-19$ & $19.1-30$ & $>30$ \\
& 1 & $0-10$ & $10.1-17$ & $17.1-25$ & $25.1-56$ & $>56$ \\
\multirow{2}{*}{ RIF- } & 2 & $0-14$ & $14.1-23$ & $23.1-35$ & $35.1-78$ & $>78$ \\
Database & 1 & $0-14$ & $14.1-23$ & $23.1-35$ & $35.1-63$ & $>63$ \\
& 2 & $0-44$ & $44.1-55$ & $55.1-64$ & $64.1-81$ & $>81$ \\
& 3 & $0-47$ & $47.1-57$ & $57.1-65$ & $65.1-84$ & $>84$ \\
\end{tabular}

494

Table 2 Difference between the number of days observed and the number of days

\begin{tabular}{|c|c|c|c|c|}
\hline \multirow{2}{*}{\multicolumn{2}{|c|}{ event }} & \multicolumn{2}{|c|}{ wildfires } & \multirow{2}{*}{ expected total } \\
\hline & & observed & not observed & \\
\hline & \multicolumn{4}{|c|}{ Contingency table. } \\
\hline \multirow[b]{2}{*}{ wildfire } & expected & a & $\mathrm{b}$ & $\mathrm{N}_{2}=\mathrm{a}+\mathrm{b}$ \\
\hline & not expected & c & $d$ & $\mathrm{~N}_{4}=\mathrm{c}+\mathrm{d}$ \\
\hline \multicolumn{2}{|c|}{ total observed } & $\mathrm{N}_{1}=\mathrm{a}+\mathrm{c}$ & $\mathrm{N}_{3}=\mathrm{b}+\mathrm{d}$ & $\mathrm{N}=\mathrm{a}+\mathrm{b}+\mathrm{c}+\mathrm{d}$ \\
\hline \multicolumn{5}{|c|}{ Calculations of the contingency table. } \\
\hline \multirow{2}{*}{ wildfire } & expected & $a /(a+c)$ & $\mathrm{b} /(\mathrm{b}+\mathrm{d})$ & 1 \\
\hline & not expected & $c /(a+c)$ & $d /(b+d)$ & 1 \\
\hline \multicolumn{2}{|c|}{ total observed } & 1 & 1 & 2 \\
\hline
\end{tabular}

495 Source: Sampaio (1999), adapted by the author.

496 Table 3 Results obtained by the percentage success for the class values of the FWI, FMA+ and RIF-Database 497 models

\begin{tabular}{cccccc}
\hline \multirow{2}{*}{ model } & \multirow{2}{*}{ subzone } & \multicolumn{3}{c}{ percentage of sucess (\%) } & \multirow{2}{*}{ Skill Score } \\
\cline { 2 - 5 } & 1 & with fire & without fire & general & \\
\hline \multirow{2}{*}{ FWI } & 2 & 59,71 & 74,38 & 72,17 & 0,2386 \\
& 3 & 57,22 & 71,14 & 69,13 & 0,1901 \\
& 1 & 62,51 & 75,49 & 73,74 & 0,1398 \\
FMA+ & 2 & 61,75 & 68,24 & 67,10 & 0,1758 \\
& 3 & 59,13 & 61,70 & 61,58 & 0,1350 \\
RIF- & 1 & 55,95 & 69,55 & 68,84 & 0,1224 \\
Database & 2 & 56,28 & 81,87 & 76,60 & 0,3545 \\
& 3 & 56,94 & 75,01 & 72,98 & 0,1868 \\
& & & 68,99 & 67,14 & 0,1993 \\
\hline
\end{tabular}

498

499 Table 4 Results found with the Shapiro-Wilk test for the different ids.

\begin{tabular}{lccc}
\hline \multicolumn{1}{c}{ Model } & Subzone & Shapiro-Wilk & Tukey-Kramer \\
\hline \multirow{2}{*}{ FWI } & 1 & 0.028 & 36.00 \\
& 2 & 0.051 & $\mathbf{3 2 . 7 8}$ \\
\multirow{2}{*}{ FMA $^{+}$} & 3 & 0.101 & 31.21 \\
& 1 & 0.004 & 35.74 \\
& 2 & 0.015 & 31.72 \\
\multirow{2}{*}{ RIF-Database } & 3 & 0.227 & $\mathbf{3 2 . 5 4}$ \\
& 1 & 0.118 & $\mathbf{3 8 . 1 3}$ \\
& 2 & 0.006 & 31.34 \\
& 3 & 0.784 & 30.52 \\
\hline
\end{tabular}

